\title{
Bob Dylan - droga do Nobla
}

Daniel Wyszogrodzki

TEKSTY DRUGIE 2018, NR 5, S. 230-256

DOI: $10.18318 /$ td.2018.5.14

\section{Wstęp: Artysta progresywny}

Bob Dylan jest artystą progresywnym w podstawowym znaczeniu tego słowa. Jego rozwój charakteryzują nieustające zmiany, jego twórczość łatwo podzielić na okresy, zupełnie do siebie niepodobne, najczęściej stojące w kontrze do siebie. Dylan przypomina pod tym względem innych wielkich artystów minionego stulecia, jak Miles Davis czy Pablo Picasso. Artystów zawsze poszukujących, często błądzących, jednak podążających własną drogą. Artystów nieliczących się z ewentualnymi negatywnymi konsekwencjami ciąłych zmian - spadkami popularności i sprzedaży. Drogę Dylana do Nagrody Nobla wyznacza dorobek chaotyczny. Noszący znamiona geniuszu, ale także dokumentujący artystyczne porażki. Obserwowany z perspektywy trwającej ponad pół wieku kariery, układa się jednak w fascynujący portret artysty, który nadał nowe znaczenie tekstom piosenki popularnej. Dzięki któremu - za sprawą Nagrody Nobla - piosenka stała się pełnoprawną formą literacką obok poezji, dramatu i prozy. Zasługiwała na to.

\section{Daniel}

Wyszogrodzki

- autor, tłumacz,

dziennikarz mu-

zyczny. Wykładowca

Akademii Teatralnej

w Warszawie (historia

muzyki popularnej

i historia musicalu).

W latach 2007-2015

kierownik literacki

Teatru Muzycznego

ROMA. Przetłuma-

czył na scenę wiele

klasycznych musicali,

m.in. Koty i Les Mi-

sérables. Autor książki

Satysfakcja-The

Rolling Stones (sześć

wydań) i poetyckich

przekładów książek

Leonarda Cohena,

m.in. Płomień (2018). 
Twórczość muzyka popularnego odmierzają płyty, jego kolejne dzieła (album to współczesny „opus”). Bob Dylan wydał około pięćdziesięciu płyt długogrających, od wielu lat ukazują się też w oficjalnym obiegu jego bogate archiwalia. Znajdziemy wśród nich kilka najważniejszych nagrań stulecia, albumy wpływowe do tego stopnia, że kształtowały styl całego pokolenia twórców. Naśladowcami amerykańskiego barda bywali najpopularniejsi europejscy muzycy lat 6o.,jak Beatlesi i Stonesi. Każdy ambitny twórca piosenek ostatnich dekad jest dłużnikiem Dylana, a konkretnie jego dwóch fundamentalnych rewolucji: rozszerzenia zarówno tematyki, jak i słownictwa piosenki. A są to dwa najważniejsze aspekty współczesnego tekstu przeznaczonego do śpiewania. Piosenka popularna może być o wszystkim i nie ma tekstów nie do zaśpiewania. Dylan udowodnił to sobie i światu.

Niejako własnym torem przebiegała ewolucja śpiewanego tekstu scenicznego (musicalowego). Co nie znaczy, że osobno, te dwie drogi rozwoju liryki śpiewanej miały się zresztą przeciąć w późnej twórczości Dylana, kiedy artysta sięgnął po repertuar tzw. Wielkiego Śpiewnika Amerykańskiego. Bob Dylan, najważniejszy autor piosenek naszych czasów, sięga bowiem regularnie po repertuar obcy. I stanowi on niezbywalną część jego portretu. Podobnie jak wszystkie jego nieudane płyty, a jest ich co najmniej tyle, co tych legendarnych. A także długie okresy twórczej impotencji, bo każdy z nich znajdował reprezentację fonograficzną i za każdym razem była ona inna. Uzupełnieniem obrazu artysty jest jego twórczość plastyczna - rysunek, malarstwo, nawet metaloplastyka. Także i w tym wypadku oryginalna, nieprzewidywalna, wymykająca się kategoriom.

\section{Nowa tradycja}

Bob Dylan pochodzi z małego miasteczka w stanie Minnesota. Dorastał w nim w czasie, kiedy stacje radiowe nadal dzieliły się na „białe” $i$,czarne”, a najbliższy ośrodek kulturalny, Chicago, pozostawał poza granicą marzeń. Radio było wszystkim. To białe grało country, to czarne - bluesa. Kiedy późniejszy noblista chodził do szkoły średniej, czyli w połowie lat 50., rodził się już rock'n'roll i związana z nim subkultura. A to oznaczało, że biała młodzież może śpiewać czarne piosenki. Ich tematyka była często nie do przyjęcia dla pokolenia rodziców - duża część repertuaru R\&B przepracowywała eufemizmy seksu. Jak choćby w utworze Shake, Rattle and Roll, który wylansował Big Joe Turner (wykonawca czarny), a spopularyzował Bill Haley (wykonawca biały). Młody Bob nasiąkał tymi wpływami, a jego ulubionym artystą był przez pewien czas Little 
Richard - uosobienie nieskrępowanej seksualnej energii. Kiedy jednak Dylan udał się na studia do Minneapolis (stolicę stanu trudno uznać za kulturalną mekkę), odkrył inną muzykę i inną tematykę. Zainteresował się muzyką folk i - wywodzącą się z ludowej tradycji - pieśnią protestu. Zapomniał na pewien czas o rock'n'rollu, absorbując muzykę, którą sam określił jako „bardziej serio”. Jego idolem stał się wielki amerykański bard, Woody Guthrie, autor tysiąca piosenek, kronikarz i komentator życia w USA. Dylan dosłownie utożsamił się z Guthriem, śpiewał jego piosenki, naśladował wygląd i styl.

Hej, Woody Guthrie, ja wiem, że to znasz

Sam o tym mówiłeś dużo głośniej niż ja

Nigdy dość nie wyśpiewam, nie starczy mi sił

Bo niewielu przeżyło to wszystko, co ty

[Song to Woody, 1962]

Ale to była tylko „rozgrzewka”. Kiedy, porzuciwszy studia, przybył do Nowego Jorku na początku lat 6o., studencka dzielnica Greenwich Village rozbrzmiewała muzyką folk, a młodzi ludzie śpiewali tradycyjne protest-songi. Dylan podbił tę scenę w ciągu kilku miesięcy - był wykonawcą zdeterminowanym, zaczynał także tworzyć własne piosenki. I to kreatywny stosunek do tradycji dał mu przewagę nad rówieśnikami. Debiutancki longplay młodego artysty, na którym znalazły się niemal same tematy tradycyjne, nie zwrócił uwagi słuchaczy, mimo doskonałych interpretacji klasyki. Ale już drugi album, The Freewheelin'Bob Dylan (1963) przyniósł przełom. Dylan napisał piosenki, które stały się hymnami całego ruchu, jak Blowin' in the Wind.

Jak wiele dróg każdy z nas musi przejść

By móc człowiekiem się zwać

Jak wiele mórz minąć ma stado mew

Nim w końcu usiądzie na piach

Jak wiele salw będzie niósł blady świt

Zanim ostatni padnie strzał

[Blowin' in the Wind, 1963]

Wielkie wrażenie robił jego oskarżycielski protest-song Masters of War, wymierzony przeciwko przemysłowi zbrojeniowemu. Największe - surrealistyczna

1 Tu i dalej utwory Boba Dylana w przekładzie autora artykułu. 
wizja nuklearnej apokalipsy, zainspirowana bezpośrednio kryzysem kubańskim, a odmalowana w pierwszej surrealistycznej pieśni Dylana A Hard Rain's a-Gonna Fall.

Widziałem niemowlę porzucone wśród wilków Autostradę z brylantów prowadzącą donikąd

Czarny las, w którym drzewa krwawiły Młoty kowalskie, co krwią żywą broczyły Białą drabinę pogrążoną w odmętach Tysiące mówców o spuchniętych językach Karabiny i miecze w rękach dzieci

[AHard Rain's a-Gonna Fall, 1963]

Ciekawe, że każda z tych piosenek była zapożyczeniem melodii ludowej. Dylan otworzył się jako poeta, zanim zaczął tworzyć oryginalną muzykę. Podobne adaptacje były wówczas czymś naturalnym. Czołowy artysta folkowy Pete Seeger ukuł termin „folk proces”, opisując zjawisko przetwarzania tradycyjnego materiału przez kolejne pokolenia artystów. Warto zwrócić uwagę, że Dylan początkowo nie odniósł sukcesu jako wykonawca. Stał się rozchwytywanym autorem, ale jego piosenki stawały się przebojami w nagraniach popularnych artystów, jak trio Peter, Paul and Mary czy folk-rockowy zespół The Byrds. Dopiero po latach wytwórnia płytowa Columbia zaproponowała slogan reklamowy „Nikt nie śpiewa Dylana, tak jak Dylan".

\section{Pierwsza metamorfoza}

Na kolejnym longplayu Dylana The Times They Are a-Changin' (1964) znalazły się prawie same protest-songi. Piosenka tytułowa stała się manifestem pokolenia.

Niech kongres i senat usłyszą nasz głos

Kto broni dostępu ten sam kusi los

Kto wita odnowę nie spadnie mu włos

Tu rozgrywa się bój zagorzały

Gmachy zadrżą w posadach i zawali się mur

Bowiem czas idzie na zmiany

[The Times They Are a-Changin', 1964] 
Młody autor nie czuł się jednak komfortowo w narzuconej roli „proroka protestu". Pisał śpiewane reportaże, a jego utwory opisywały po nazwisku ofiary przemocy i niesprawiedliwości, np. Ballad of Hollis Brown czy The Lonesome Death of Hattie Carroll. Do śmiałości w dramatycznym rysunku postaci zachęciła go twórczość Kurta Weila. Inspirowany gorącymi tematami, Dylan wpisywał się w tradycję „topical song”, piosenki zaangażowanej. Od samego początku kariery młody twórca był niesłychanie płodny, pisał znacznie więcej piosenek, niż mogły pomieścić jego płyty. I podobnie jego pomysły językowe nie mieściły się w ograniczonych ramach ludowej ballady, od jakiej zaczynał jako muzyk. Muzyka akustyczna i ascetyczna formuła solowych występów także się wyczerpywały. W powietrzu wisiało coś elektryzującego...

Nie chcę o nic z tobą grać

Wygrać, przegrać, plamę dać

Nie chcę cię klasyfikować

Szeregować, ukrzyżować

Bo jedyne, czego chcę

To zaprzyjaźnić się

[All I Really Want to Do, 1964]

Na początku Dylan rozszerzył formułę literacką. Jego nowy album, wydany jeszcze w tym samym roku, nosił tytuł Another Side of Bob Dylan, czyli Dylan od innej strony. I był przełomem. Nie zawierał piosenek zaangażowanych, a do poetyckich inspiracji artysty zaliczano symbolistów (Rimbaud) i beatników (Ginsberg). Dylan rozwijał się. Jego piosenki z tego okresu dosłownie rozsadzały ramy muzyki tradycyjnej.

Autostrada jest dla graczy - czy ty umiesz grać?

Pilnuj tego, co przypadek był ci łaskaw dać

Uliczny malarz z miasta twoich snów

Na pościeli twej nakreślił dziwny wzór

Niebo ścieli się u twoich stóp

Wszystko już skończone, Baby Blue

[It's All Over Now, Baby Blue, 1965]

Sceniczne występy Dylana (m.in. osławione partie solowe na harmonijce ustnej) emanowały energią, która wymagała nowej muzyki, nowych środków wyrazu. Jego koncerty w Anglii w 1965 roku zaowocowały radykalną zmianą 
koncepcji muzycznej - słuchając Beatlesów i Stonesów chłopak z Minnesoty zrozumiał, że brytyjska młodzież fascynuje się brzmieniami znanymi mu od co najmniej dekady. Postanowił wrócić do korzeni amerykańskiej muzyki, do bluesa, R\&B, rock'n'rolla. Na następnej płycie w części utworów po raz pierwszy wystąpili z nim zaproszeni muzycy. Longplay przyjął nietypową formę pośrednią: pierwsza strona płyty była „elektryczna”, druga „akustyczna”. Koncert Dylana z zespołem rockowym na Festiwalu Folkowym w Newport w 1965 wywołał kontrowersje - dla części swojej publiczności stał się „zdrajcą", który odchodzi od ruchu praw człowieka na rzecz muzyki komercyjnej. Tymczasem talent poetycki Dylana, wzmocniony energią nowej muzyki, zaczynał rozwijać się na nowo. Nastąpiło otwarcie idące tak daleko, że... przypisywano je wpływowi narkotyków. Najbardziej znanym przykładem surrealistycznych wizji z longplaya Bringing It All Back Home (1965, znamienny tytuł) stał się przebój wylansowany przez grupę The Byrds:

Hej, Panie Tamburynie, śpiewkę zagraj mi

Nie mam celu i zbudziłem się wyspany

Hej, Panie Tamburynie, śpiewkę zagraj mi

W ten poranek rozedrgany

Chcę za tobą iść

[Mr. Tambourine Man, 1965]

Dylan coraz bardziej fantazyjnie śpiewał o kobietach:

Moja miła mówi ciszą

Jej ideały nie krzyczą

Nie dowodzi wcale, że jest wierna

Jest jak lód, jak płomień szczera

Ludzie noszą róże

I obiecują za dużo

Ona się śmieje kwieciście

Niczym przekupić się nie da

[Love Minus Zero/No Limit, 1965]

I coraz bardziej sarkastycznie:

Ona ma wszystko, czego chce

Jest artystką, nie patrzy wstecz 
Ona ma wszystko, czego chce Jest artystką, nie patrzy wstecz Może odebrać nocy ciemność I zamalować dzień

[She Belongs to Me, 1965]

Dwa kolejne albumy Boba Dylana zmieniły historię muzyki popularnej. Były to płyty Highway 61 Revisited (1965) i Blonde on Blonde (1966). Na tej pierwszej znalazł się utwór Like a Rolling Stone, który w plebiscycie magazynu „Rolling Stone" na nowe millenium znalazł na szczycie listy najważniejszych piosenek rocka. Zwracała uwagę Ballada o szarym człowieku, ukazująca zderzenie nieprzygotowanej jednostki ze zmieniającym się, nieprzestrzegającym żadnych reguł otoczeniem:

Wszedł pan do pokoju

$\mathrm{Z}$ długopisem w dłoni

Stał tam ktoś nagi, spytał pan:

Kim jest ten człowiek?

I bezskutecznie

Próbował pan pojąć

Co też pan powie

O tym w domu

Bo coś się tu dzieje

A pan nie wie, co to jest

Nieprawda, panie Jones

[Ballad of a Thin Man, 1965]

Słowa jej refrenu weszły na stałe do języka potocznego, a przysłowiowy „pan Jones" stał się symbolem człowieka konserwatywnego, nienadążającego za zmianami. Nie po raz pierwszy Dylanowskie frazy przenikały do języka, było tak od początku.

Nawet Jezus tych czynów nie wybaczyłby wam

[Masters of War, 1963]

Bo sam prezydent USA czasami też staje nagi

[It's Alright, Ma (I'm Only Bleeding), 1964] 
Nie potrzeba synoptyka

Żeby wiedzieć, w którą stronę wieje wiatr

[Subterranean Homesick Blues, 1965]

Pisarstwo Dylana stawało się jednocześnie coraz bardziej osobiste i coraz bardziej abstrakcyjne. Jego opus magnum z tego okresu to utwór Desolation Row:

Einstein w przebraniu Robin Hooda

Z kuferkiem wspomnień swych

Przeszedł tu z godzinę temu

A wraz z nim zazdrosny mnich

Źle wyglądał w sposób tak niewinny

Że o fajkę wnet doprosił się

Odszedł stąd obwąchując rynny

I recytując po kolei a-b-c

Choć wydaje się tak niepozorny

To i on pięć minut swoje miał

Kiedy na skrzypcach elektrycznych

W Alei Spustoszenia grał

[Desolation Row, 1965]

Słuchacze rocka, były to już bowiem nagrania stricte rockowe, towarzyszyli artyście w fascynującej podróży do wnętrza, zaludnionego przez osoby realnie istniejące, a także przez bohaterów mitycznych i literackich. W fantazyjnej podróży wyobraźni, w której biblijny Abraham mijał się z Szekspirem, Beethoven z Einsteinem, zaś Fidel Castro z Ezrą Poundem albo T.S. Eliotem. Finezji nabrała w tym okresie twórczość liryczna Dylana, a to za sprawą portretów kobiet, tak chętnie malowanych przez niego w piosenkach. Zazwyczaj kobiet związanych z artystą: Visions of Johanna (Joan Baez), Sad Eyed Lady of the Lowlands (Sara Lownds, żona Dylana).

Ten deszcz koi ból

A ja stoję w jego strugach właśnie tu

Wszyscy wiedzą, że maleństwo stroi się

Lecz wstążek i kokard jest w jej włosach coraz mniej

Bo zaczęła gubić je 
Kulminacją tego okresu było światowe tournée Boba Dylana z grupą The Hawks (później The Band). Gdy poeta grał solo w części akustycznej występów, publiczność była w euforii. W drugiej części koncertu towarzyszył mu doskonały zespół rockowy, ale regularnie bywał przyjmowany gwizdami. To właśnie doświadczenie ostatecznie uzmysłowiło Dylanowi, że wyprzedza swoją publiczność i sprawiło, że odciął się definitywnie od wszelkich oczekiwań i ocen.

\section{Druga metamorfoza - ucieczka}

Po serii przełomowych albumów i legendarnym tournée Bob Dylan był na szczycie i stał się światową gwiazdą. Co więcej, stał się wzorem do naśladowania. Jego teksty dały impuls całemu pokoleniu artystów do zmiany stylu pisania piosenek. Ci wielcy, słynni autorzy ze spółek Lennon/McCartney i Jagger/ Richards, przyznawali się wprost do fascynacji twórczością amerykańskiego idola. Kiedy jednak Dylan znalazł się na szczycie, nagle przepadł. Pretekstem do ucieczki był wypadek motocyklowy, zapewne mniej groźny, niż wówczas spekulowano. Dylan zszedł z rockowej sceny, oddalił się od nowojorskich studiów nagraniowych i znalazł schronienie w sielankowym wiejskim domu pod Woodstock, artystyczną kolonią o wieloletniej tradycji. Mieszkał z żoną, przychodziły na świat ich dzieci. W pobliżu osiedlili się też muzycy towarzyszący Dylanowi w ostatnim tournée. Ostatecznie namaszczeni na The Band - byli jedynym „Zespołem” w okolicy - przystąpili do nagrań w zaimprowizowanym piwnicznym studio. Raz z szefem, innym razem bez niego. I tak rodziły się The Basement Tapes, owiane legendą „taśmy z piwnicy”, na które czekali słuchacze.

Jeśli pamięć dobrą masz

Wiesz, co jeszcze czeka nas

Rozpakuję więc walizki

I usiądę póki wciąż jest czas

Nikt z żywych cię nie znajdzie by

Opowiedzieć nową baśń

A ty wiesz, że znowu spotkasz mnie

Jeśli pamięć dobrą masz

[This Wheel's on Fire, 1967]

Ku zaskoczeniu fanów Dylan nie wydawał nowej płyty. Udostępniał materiał innym artystom i to $\mathrm{z}$ ich interpretacji można było odczytać 
nowe współrzędne twórcy na kulturalnej mapie Ameryki. A była to istotnie cała mapa. W piwnicy pod Woodstock Dylan \& The Band stworzyli nową kategorię muzyczną, określaną od tamtej pory jako „Americana”. Stanowi ona syntezę - potraktowanych bez namaszczenia - wszystkich stylów rdzennych (blues, folk, gospel, spirituals, rockabilly) wzbogaconą wyobraźnią poetycką Dylana. Świat stopniowo odkrywał kolejne rąbki tajemnicy. A piosenki obecnie kluczowe dla kanonu Dylana, jak np. I Shall Be Released, nagrana przez The Band, ale bez udziału autora - dawały świadectwo nowej głębi, jaka pojawiła się w tekstach Dylana po wycofaniu się z "gwiazdorskiego" życia.

Jak nie ty, to inny - mówią ludzie

Jednak własną drogą wolę iść

I dokładnie w myślach zapisuję

Tak wiele twarzy, tyle chwil

Budzi się blask nade mną

Od zachodu, aż po wschód

Lada dzień już, wiem na pewno

Wolny będę znów

[IShall be Released, 1967]

Poza wszystkim Bob Dylan i fenomenalni kanadyjscy muzycy z The Band doskonale się bawili. Kiedy kilka lat później grupa rozpoczęła karierę pod własnym szyldem, stało się tradycją umieszczanie nieznanych piosenek byłego szefa na jej płytach:

Spieszę do siostrzenicy Botticelliego

W moim hotelu randkę dziś z nią mam

Obiecała być razem ze mną

Kiedy swe arcydzieło będę malował ja sam

[When I Paint my Masterpiece, 1971]

Dylan stawał się coraz większym introwertykiem, a dowodem jego postępującej alienacji była odmowa występów, a także niezrozumiała dla publiczności polityka nagraniowa. Zamiast wydać, oczekiwane już na całym świecie „Taśmy z piwnicy”, owoc współpracy z The Band, artysta udał się nagle samotnie do Nashville, gdzie w towarzystwie kilku muzyków studyjnych 
zarejestrował zupełnie nowe utwory na znakomitej, ascetycznej płycie John Wesley Harding (1967).

John Wesley Harding

Przyjacielem biednych był

Ze spluwą w ręku

Zjeździł cały kraj

A choć na swojej drodze

Otwierał wiele drzwi

Nie słyszano by

Człek prawy się go bał

[John Wesley Harding, 1967]

Płytę otwierała prosta ballada o rewolwerowcu, stylizowana na opowieść z Dzikiego Zachodu. Większość nowych piosenek układała się jednak w cykl apokryficznych przypowieści stylizowanych na tekst biblijny, jak w All Along The Watchtower.

Musi być stąd jakieś wyjście - rzekł Błazen do Złodzieja

Tak wiele pomieszania, tak mało ukojenia

Kupcy piją moje wino, parobcy ryją moją ziemię

Ile to wszystko jest warte, tego już żaden z nich nie wie

[All Along the Watchtower, 1967]

Dylan tworzył współczesne apokryfy:

Świętego Augustyna

Widziałem raz we śnie

Znalazłem się wśród tłumu

Który wydał go na śmierć

Zbudziłem się wzburzony

Bo nadal czułem strach

Oparłem się o szybę

I płakałem kryjąc twarz

[IDreamed I Saw St. Augustine, 1967]

Niektóre piosenki z tego okresu nawet dzisiaj mogą wydawać się prorocze: 


\section{Żal mi biednego imigranta \\ Który w błocie musi brnąć \\ Nosi w ustach sztuczny uśmiech \\ Wznosi miasto własną krwią}

[IPity the Poor Immigrant, 1967]

Albumem John Wesley Harding ( $\mathrm{z}$ „Piwnicznymi taśmami” w zawieszeniu) Dylan zamykał bezprecedensową passę twórczą trwającą przez dokładnie trzy lata: 1965-1967. Interesujące, że konkludowała ten okres piosenka nieomal banalna, lecz banalna z wyboru. Sielski, rodzinny tryb życia pod Woodstock zmienił Dylana. Już nie był buntownikiem i z pewnością nie starał się być prorokiem. Pisał o miłości.

$$
\begin{aligned}
& \text { Za oknem właśnie umilkł drozd } \\
& \text { Już odlatuje } \\
& \text { Księżyc świeci jak srebrny trzos } \\
& \text { Niech nam wtóruje } \\
& \text { Nie pożałujesz }
\end{aligned}
$$

[I'll Be Your Baby Tonight, 1967]

Nowa faza znalazła wyraz w muzyce country, najlepiej oddającej stan artysty zmęczonego rolą idola. Od tej pory twórczość Dylana będzie jednak nierówna, poszarpana amplitudą wzlotów i upadków. W nagraniach country z końca dekady, uwiecznionych na krótkiej płycie Nashville Skyline (1969), artysta nie zapominał o korzeniach rock'n'rolla. Wychował się, tak jak całe jego pokolenie, na piosenkach Elvisa Presleya. Ale on sam swingował jak najlepszy śpiewak z Południa.

Być z tobą sam na sam

Tylko ja i ty

Nareszcie prawdę znam

Wiem jak powinno być

Niech więc tętni noc

Rytmem naszych ciał

Nie ma problemów gdy

Jesteśmy sam na sam 


\section{Rozwód jako akt sceniczny}

Dylan wrócił na sceny w 1974 roku. A właściwie na stadiony, była to bowiem dekada, w której rock zaczął przerastać sam siebie. Trasa koncertowa Bob Dylan \& The Band promowała studyjny album tej formacji Planet Waves (1974), ale znalazły się na nim wyłącznie premierowe piosenki. Był konglomeratem wcześniejszych wątków, ale osobne miejsce zaczęły mieć utwory komentujące - coraz bardziej burzliwe - małżeństwo artysty, jak Wedding Song. Znalazła się na nim także, dedykowana synowi, piosenka Forever Young, hymn wiecznej młodości, zawierający chyba najbardziej pozytywne przesłanie w całej twórczości barda.

Oby Bóg cię błogosławił

Twym pragnieniom posłuch dał

Obyś dawał siebie innym

I od innych chętnie brał

Obyś schody wzniósł do nieba

I zdobywał każdy szczyt

Obyś wiecznie młody był

[Forever Young, 1974]

W międzyczasie Dylan stworzył i nagrał muzykę do filmu Sama Peckinpaha Pat Garrett $\odot$ Billy the Kid z 1973 roku. To z tego mistrzowskiego „antywesternu", w którym muzyka Dylana, głównie instrumentalna, stała się integralną częścią opowieści, pochodzi klasyczny przebój artysty, Knockin' on Heaven's Door.

Niech strzelby moje skryje piach

Już żaden strzał nie padnie z nich

Nadchodzi zmierzch, czuję się tak

Jakbym pukał do nieba drzwi

[Knockin' on Heaven's Door, 1973]

Ale wszystko to było zaledwie wstępem do drugiej passy twórczej, której owocem stał się tryptyk albumów nagranych przez artystę w drugiej połowie lat 70. Otwiera go płyta Blood on the Tracks (1975), uważana obecnie za Dylanowskie arcydzieło - najbardziej osobisty z jego albumów, najsilniej przesycony emocjami: 
Miłość jest prosta, ktoś ujął to tak

Zrozumiałaś to dawno, ja dopiero w tych dniach

Wiem, gdzie mogłaś się skryć, to jakiś obcy dom

Spłacę to, co muszę - jesteś już naprawdę duża

[You're a Big Girl Now, 1974]

W poprzednich latach Dylan dawał liczne dowody bezkompromisowości, choćby atakując hipokryzję środowiska Greenwich Village - tego samego, które na fali popularności pieśni protestu na własnych ramionach wyniosło go do sławy.

Masz jeszcze czelność
Przyjacielem zwać mnie swym
Gdy upadłem
Stałeś szczerząc zęby
Masz jeszcze czelność
Oferować pomoc mi
Ty chcesz zaistnieć przy tym
Kto zwyciężył

[Positively 4th Street, 1965]

Tym razem jednak obiektem ataku stała się żona artysty, początkowo traktowana jako „kobieta uniwersalna”, fatum, wyrok. Bohaterka piosenek materializowała się jednak w miarę postępującej dezintegracji małżeństwa Dylanów. Artysta nigdy nie komentował wypowiedzi krytyków, ale kiedy usłyszał, że ktoś słuchał tego albumu z przyjemnością, zapytał: Jak można czerpać przyjemność z takiego bólu? W połowie lat 70. trzech wielkich poetów piosenki - poza Dylanem także Leonard Cohen i Paul Simon - wydało znakomite albumy poświęcone "tematyce rozwodowej”. Simon pisał o rozpadzie związku z rezygnacją. Cohen z typową dla siebie dwubiegunowością. I tylko u Dylana paliwem był gniew. I negatyw gniewu, jakim jest rozpacz.

Na kolejnym udanym albumie, Desire (1976), pojawił się jeden z najbardziej nieszablonowych utworów w całym dorobku Dylana, zatytułowany Isis - parabola małżeństwa rozumianego jako nieustający cykl, a więc... pozostawiająca nadzieję. 
Ożeniłem się z Isis piątego dnia maja

Lecz nie mogłem u boku jej wytrwać zbyt długo

Obciąłem więc włosy i ruszyłem w nieznane

Do odległej krainy, gdzie każdemu się uda

\section{[Isis, 1975]}

O uczuciowym rozdarciu, jakie towarzyszyło powstaniu tych piosenek, najlepiej świadczy fakt odrzucenia w ostatniej chwili pięknego utworu $A b$ dandoned Love. Nagranie, udostępnione oficjalnie po latach, przekonuje, że mogło stać się ozdobą albumu, prawdopodobnie Dylan uznał, że za bardzo się w nim odsłonił:

Mój święty patron z duchem wiedzie bój

Zapodziewa się, zamiast walczyć właśnie tu

Hiszpański księżyc wstaje pośród wzgórz

A serce mówi mi, że cię kocham wciąż

[Abandoned Love, 1975]

Na tournée, jakie pod nazwą Rolling Thunder Revue zorganizował Dylan na przełomie lat 1975/1976, pojawiała się zarówno żona artysty, Sara, jak jej wielka poprzedniczka, Joan Baez (trójkąt ten stał się tematem filmu dokumentalnego Renaldo $\Theta$ Clara, zrealizowanego przez samego Dylana). Ale pod koniec trasy koncertowej separacja stała się permanentna. Artysta odreagowywał jej skutki, tworząc materiał na - zamykający tryptyk - album Street Legal (1978).

Señor, señor, może wie pan, co jest celem Lincoln County Road czy Armagedon?

[Señor (Tales of Yankee Power), 1978]

Piosenką Is Your Love In Vain [Czy zmarnować miłość chcesz] Dylan naraził się na krytykę środowisk feministycznych, które zarzucały mu stosowanie stereotypu kobiety podporządkowanej mężczyźnie i przedmiotowe traktowanie kobiet.

Ty nie widzisz w biegu

Że ja samotność muszę mieć 
Czasem pragnę trwać w ciemności

Więc dlaczego wdzierasz się

Czy ty znasz mój świat, czy znasz takich jak ja

Czy cokolwiek o mnie wiesz

Pozwolisz mi być sobą

Czy zmarnować miłość chcesz?

[Is Your Love in Vain?, 1978]

\section{Wygwizdany kaznodzieja}

Z prawdziwie zmasowaną krytyką, i to o skali, która zaskoczyła obserwatorów, artysta spotkał się dopiero po wejściu w kolejną fazę twórczości i życia, jaką stało się... chrześcijaństwo. Urodzony jako Robert Zimmerman w żydowskiej rodzinie o korzeniach wschodnioeuropejskich, późniejszy Bob Dylan wyrastał w tradycji judaistycznej. Nieoczekiwane nawrócenie wprawiło publiczność w niemałą konsternację, choć kontekst religijny wypływał u Dylana już wcześniej.

Och, Siostro, proszę, za brata mnie miej

Czyż nie wart jestem uczucia?

Ojciec w miłości wyznaczył nam cel

Przestrzegaj Jego pouczeń

[Oh, Sister, 1975]

Dylan doznał objawienia w listopadzie 1978 roku w pokoju hotelowym w Arizonie w trakcie trasy koncertowej. Pierwszym owocem fascynacji postacią Jezusa był album Slow Train Coming (1979), jak miało się okazać, pierwszy z religijnej trylogii. Płyta została doskonale przyjęta przez krytykę, a sam wokalny popis Dylana w piosence-litanii Gotta Serve Somebody nagrodzono Grammy.

Możesz być ambasadorem w Anglii lub we Francji

Możesz lubić hazard, możesz lubić tańczyć

Możesz być mistrzem świata w boksie wagi ciężkiej

Możesz być kimś z wyższych sfer i szastać pieniędzmi

Ale będziesz musiał służyć komuś

O tak, będziesz musiał służyć komuś 
Może to być diabeł, a może to być Pan

Ale będziesz musiał służyć komuś

[Gotta Serve Somebody, 1979]

Potem było gorzej. Porywający gospel-rock z albumu Saved (1980) należy do najciekawszych osiągnięć muzycznych artysty. Niestety, jego teksty stały się monotematyczne. Dylan śpiewał już tylko o Jezusie i łasce zbawienia.

Jesteś gotów? Jesteś gotów?

Jesteś gotów? Jesteś gotów?

Jesteś gotów na Jezusa?

Odnalazłeś miejsce? Gdzie?

Czy na pewno cię rozpozna

Czy też powie: „Nie znam cię”

[Are You Ready, 1980]

Nie koniec na tym. Dylan, z zapałem neofity, zaczął wykonywać na koncertach wyłącznie nowy, „religijny” materiał. Tego było za wiele nawet dla najbardziej oddanych fanów - nie wyobrażali sobie koncertów artysty bez piosenek sprzed objawienia. Dylan ostentacyjnie odrzucił cały poprzedni dorobek, a publiczność - odrzuciła Dylana. A szkoda, bo koncerty z lat 1979/1980 pod względem muzycznym należą do jego najlepszych. Płyta Shot of Love (1981) była już kompromisem. Znalazł się na niej świecki portret komika Lenny Bruce, a utwory religijne nabrały uniwersalizmu i subtelności (Every Grain of Sand). Obu tych cech brakowało Dylanowi prozelicie. Do repertuaru koncertowego artysty zaczęły powracać ulubione piosenki sprzed lat. Dylan-chrześcijanin to dziś epizod, ale jego wiara była szczera.

Wierzę w ciebie tak, kiedy śmieję się i płaczę

Wierzę w ciebie tak, kiedy jestem całkiem sam

Wierzę w ciebie tak, kiedy zrywam się nad ranem

Och, kiedy dzień się budzi

Och, kiedy noc odchodzi

Ja w sercu wiarę mam 


\section{Pojawia się próżnia}

Nowa dekada nie była dla Dylana szczęśliwa. Po trzech albumach w mniejszym lub większym stopniu religijnych artysta wydał płytę Infidels (1983) i powrócił do łask. Jak miało się okazać - nie na długo. Otwierał ją ważny utwór Jokerman, dopiero po latach wyszło na jaw, jak znakomite nowe piosenki, nagrane w czasie sesji do Infidels, nie znalazły się na ostatecznej wersji albumu.

Stoisz nad wodami rozrzucając chleb

Kiedy oczy bożka o żelaznym łbie jaśnieją

Odległe statki giną we mgle

Przyniósł cię huragan, a wąż dłonie twe oplatał

Wolność, wolność mógłbyś znaleźć raz dwa

Lecz wyrzekłeś się prawdy, więc na co wolność się zda

Ruszaj w tan, Błaźnie, ruszaj w tan

Słowik śpiewa noc do tańca ci gra

Błaźnie - och... Ruszaj w tan!

[Jokerman, 1983]

Niestety, był to początek równi pochyłej. Płyta Empire Burlesque (1985) była chybioną - pod względem muzycznym - próbą nawiązania do brzmień lat 8o., co nie pomogło nawet najlepszym utworom, jak Tight Connection to My Heart (Has Anybody Seen My Love). Sama próba wpisania Boba Dylana w modne trendy z dzisiejszego punktu widzenia wydaje się absurdalna. Wygrywały aranżacje najprostsze, jak w rockowym utworze Trust Yourself.

Jesteś zdany na siebie, zresztą zawsze byłeś

W krainie wilków i złodziei

Nie pokładaj nadziei w zamysłach bezbożników

Nie bądź niewolnikiem obcych idei

Ufaj sobie

A nie poczujesz się dotknięty, gdy cię prostak upokorzy

Ufaj sobie

I nie szukaj odpowiedzi tam, gdzie znaleźć ich nie możesz

Nie ufaj, że pokażę ci miłość

Nie poznasz czy to miłość czy chuć 
Potrzebny ci ktoś zaufany?

Ufaj sobie

[Trust Yourself, 1983]

Bob Dylan miał przed sobą wieloletnią blokadę pisarską, co jednak nie powstrzymało go przed wydawaniem płyt - tym razem najgorszych od czasu debiutu. O jego słabnącej wenie twórczej świadczyła nie tylko spadająca jakość autorskich tekstów, wyprutych nagle z oryginalności i finezji, ale fakt coraz częstszego nagrywania utworów innych twórców. Album Knocked Out Loaded (1986) ratowała zaledwie jedna kompozycja, filmowa w skali (i faktycznie bazująca na filmie) Bronsville Girl, jej współautorem był znany dramaturg i aktor Sam Shepard.

Oglądałem kiedyś niezły film

O facecie wędrującym konno przez pustynię - grał w nim Gregory Peck

Facetowi strzelił w plecy młody rewolwerowiec spragniony rozgłosu

Miejscowi chcieli powiesić go na drzewie, załatwić od razu

Płyty Down in the Groove (1988) nie ratowało już nic poza udziałem znakomitych muzyków, m.in. zespołu The Grateful Dead. Sprzedaż albumów artysty spadła tak dalece, że wytwórnia Columbia, z którą był związany od początku kariery, rozważała nieprzedłużenie umowy. Dylan nie umiał sobie radzić z blokadą pisarską. Kiedy i w następnej dekadzie ponownie opanowała go niemoc twórcza, zareagował inaczej. Zamiast wydawać niedobre płyty, nagrał dwa cykle utworów ludowych - solo, przy akompaniamencie gitary i harmonijki. Brzmiał tak, jak na swoich pierwszych płytach, olśniewał techniką instrumentalną, odkrywał zapomniane folkowe ballady dla nowej publiczności. Nagrania ukazały się na dwóch albumach: Good as I Been to You (1992) oraz World Gone Wrong (1993). Zabrakło na nich jednak autorskich piosenek Dylana, a to przede wszystkim na nie czekali słuchacze.

\section{Czy zmarnować utwór chcesz?}

A jednak dobrych piosenek Dylana było więcej, po prostu nie trafiały na jego płyty. Zbiór niepublikowanych utworów artysty rozrastał się od dnia jego debiutu. Dylan jest płodnym twórcą, a jego kolejne „opusy” - najpierw longplaye, następnie płyty kompaktowe - zawierały zazwyczaj wybór piosenek powstających w danym okresie. Artysta wykonywał na koncertach utwory nieznane z nagrań studyjnych i część z nich zdobywała znaczną popularność. 
Utwory takie jak Talkin'John Birch Paranoid Blues (polityczna satyra z 1962 roku na temat „polowania na czarownice"), przechodziły do legendy Dylana, chociaż nie było ich na płytach.

\section{Eisenhower to rosyjski szpieg \\ Lincoln, Jefferson, no i Roosevelt też}

[Talkin'John Birch Paranoid Blues, 1962]

Artysta nagrywał w studio dziesiątki piosenek, a ostateczny wybór utworów, które trafiały na oficjalną edycję, niejednokrotnie mógł wprawiać w zdumienie. Ewidentnie Dylan nie był najlepszym krytykiem własnej twórczości. Początkowo były to pieśni protestu, popularyzowane przez innych wykonawców, tak jak Percy's Song w nagraniu brytyjskiej grupy folkowej Fairport Convention:

Zła wieść, zła wieść przerwała mi sen

Wróć, wróć, cofnij się

Jeden z mych przyjaciół w tarapatach znalazł się

Wróć, wróć na wiatr i na deszcz

\section{[Percy's Song, 1963]}

Pomijano utwory tak ważne, jak np. Lay Down Your Weary Tune - ogniwo, które łączy symbolizm Hard Rain z introspekcją tekstów z okresu „elektrycznego".

Zwierciadło rzeki nie ma dna

Gdy w nim przeglądam się

A woda płynie niczym hymn

Jej nurt ma harfy dźwięk

Steraną piosnkę odłóż w kąt

Już przestań brzdąkać ją

I poddaj się sile takich strun

Których nie odda głos

[Lay Down Your Weary Tune, 1963]

Piosenki pominięte przez Dylana na płytach rock'n'rollowych z lat 1965-1966 stanowią niemal osobny kanon. Taki los spotkał już akustyczną balladę Farewell Angelina (spopularyzowaną przez Joan Baez), taki los spotkał 
także utwór She's Your Lover Now o złożonej, kompleksowej narracji, zapowiadającej teksty z następnej dekady (i nagrany z The Band). Szalę goryczy przelały jednak nagrania z Woodstock z okresu „piwnicznego". Wykradzione ze studia doczekały się szerokiej dystrybucji w drugim obiegu (tzw. bootlegi) i przyczyniły się do powstania osobnej branży fonograficznej, skupionej na wydawaniu nieoficjalnego materiału - najczęściej koncertowego (co interesujące, inną artystką, którą dotknęła plaga bootlegów, była wielka śpiewaczka operowa, Maria Callas). Wytwórnia płytowa Columbia dopiero na początku lat 9o. zaczęła robić użytek ze skarbów, jakie znajdowały się w jej archiwach (wcześniej, bo w 1975 roku, ukazała się okrojona edycja The Basement Tapes). Seria archiwaliów, nazwana przewrotnie The Bootleg Series, ukazuje się od 1991 roku i okazała się dla Columbii żyłą złota. Rok 2017 przyniósł trzynastą już część nagrań niepublikowanych, które do tej pory (w rozszerzonych edycjach deluxe) zajęły w sumie ponad sto (!) dysków kompaktowych.

\section{Serial: wielkie powroty}

Po okresach spadku kreatywności następowały w twórczości Dylana pozytywne przełomy. Album Infidels z 1983 roku przyjęto z ulgą, jako powrót do twórczości „świeckiej” po fazie religijnej. I mógł to być „wielki powrót”, gdyby na oficjalnym albumie nie zabrakło kilku z najważniejszych piosenek napisanych w tym czasie i odłożonych do lamusa, jak Blind Willie McTell i Foot of Pride. Innym „wielkim powrotem” była świetna płyta Oh Mercy (1989), nagrana w Nowym Orleanie pod kierunkiem wybitnego producenta muzycznego Daniela Lanois'a. Przywracała nadzieję zamykając nieudaną dekadę. Ale sytuacja powtórzyła się. Mimo krótkiego czasu trwania (38:45) i na ten album nie weszły piosenki znakomite i ważne: Series of Dreams i Dignity. Niestety, następne płyta artysty, Under the Red Sky (1990), znowu rozczarowywała, mimo udziału całej plejady gwiazd światowej muzyki. Odwoływała się tyleż do amerykańskich korzeni, co do dziecięcych rymowanek.

Kotek w studni, konik gdzieś patataj

Kotek w studni, a konik gdzieś patataj

Szybka Sally w oddali wierzchem gna przez USA

[Cat's in the Well, 1990]

To właśnie wtedy Dylan-autor poddał się na kilka lat i pozwolił Dylanowi-wykonawcy nagrać dwie płyty z muzyką folk. Natomiast prawdziwy wielki 
powrót Dylana nastąpił dopiero wtedy, kiedy nikt już właściwie nie liczył na znaczący wpływ tego artysty na współczesną muzykę, czyli pod koniec lat 90. Wydaniem albumu Time Out of Mind (1997) Dylan rozpoczął trzeci - po latach 6o. i drugiej połowie lat 70. - imponujący cykl twórczy. Objął on w sumie trzy płyty, dwie kolejne to Love and Theft (2001) i Modern Times (2006). W tym samym okresie Bob Dylan zdobył Oscara za piosenkę Things Have Changed napisaną do filmu Cudowni chłopcy z 2000 roku.

Ludzie szaleją, straszny wiek

Zamykam się, oddalam się

Zależało mi, ale dziś już nie

[Things Have Changed, 200o]

„Powrotów” Dylana byłoby jeszcze więcej, gdyby odmierzać je nagrodami. Ma w dorobku trzynaście Grammy, ma także dwa doktoraty honoris causa za muzykę (w tym Uniwersytetu Princeton). Jest laureatem Polar Music Prize (2000), nazywanej „muzycznym Noblem”. Ma także Pulitzera - za "głęboki wpływ na muzykę popularną i amerykańską kulturę, ze szczególnym uwzględnieniem kompozycji o wyjątkowej sile poetyckiej". W 2007 roku otrzymał prestiżową Nagrodę Księcia Asturii (w kategorii sztuka, dopiero Leonard Cohen w 2011 roku, jako pierwszy piosenkarz, zostanie nagrodzony w kategorii literatura), oraz dwa najwyższe odznaczenia francuskie: Ordre des Arts et des Lettres (Order Sztuki i Literatury, 1990) i Legię Honorową (2013). Prezydent Barack Obama odznaczył Dylana najwyższym odznaczeniem cywilnym w Stanach Zjednoczonych, Medalem Wolności (2012). Bob Dylan jest drugim człowiekiem w historii, który otrzymał literackiego Nobla i Oscara. Pierwszym był... George Bernard Shaw. Wybitny dramaturg i prozaik irlandzki został laureatem literackiego Nobla już w 1925 roku, natomiast w roku 1938 zdobył Oscara za... scenariusz ekranizacji dramatu Pigmalion (i miał powiedzieć, że Nagroda Akademii to obelga, bo w Hollywood i tak nikt o nim nie słyszał). Shaw i Dylan, ten ekskluzywny „klub” nieprędko się powiększy o kolejnego członka.

Codziennie pamięć blednie

Nawet ona coraz rzadziej ze mnie drwi

Błąkając się bez celu usiłuję

Dostać się do nieba zanim zamkną drzwi 


\section{Mitologia Delty}

Przełom milenijny oznaczał w twórczości Boba Dylana trzeci - i jak dotąd ostatni - kreatywny wzlot owocujący serią znakomitych nagrań. Przypomnijmy: (I) 1965-1967, (II) 1974-1979 i (III) 1997-2006. Nieuchronnie pojawiły się oznaki kolejnego kryzysu. Na płycie Together Through Life (2009) Dylan podparł się współautorem, był nim współpracownik grupy The Grateful Dead, autor tekstów Robert Hunter. Tempest (2012), to płyta nierówna, jednak z kilkoma wybitnymi utworami (m.in. Long and Wasted Years, Pay in Blood, Scarlet Town). Część amerykańskich krytyków uznała ją za kontynuację wspaniałej passy Dylana z przełomu milenium. Te ostatnie dzieła ukazują innego Dylana, niż ten, do którego przywykli słuchacze (jeżeli w ogóle można „przywyknąć” do artysty równie nieprzewidywalnego). Można powiedzieć, że Dylan zatoczył pełen krąg, choć raczej nie wrócił do punktu wyjścia. Rozpoczynał od skrupulatnej analizy amerykańskiej muzyki - ludowej, lecz nie tylko. Szukał własnego miejsca w niekończącej się, płynącej niczym odwieczna rzeka, balladowej narracji. Imitował ją, przetwarzał, parodiował. Robił to zresztą od samego początku.

Listy gończe w Kalifornii, listy gończe w Buffalo Listy gończe w Kansas City, listy gończe w Ohio Listy gończe w Missisipi i w Cheyenne nie od dziś Nie rozglądaj się wokoło, wszędzie wisi gończy list

[Wanted Man, 1969]

Teraz, jako artysta dojrzały i niemłody już człowiek, tworzył syntezę swoich źródeł. Począwszy od przełomowego albumu Time Out of Mind z 1997 roku, Dylan stosuje coraz więcej zapożyczeń, zarówno w warstwie muzycznej, jak i literackiej. Ciekawe, że czynił to samo jako debiutant. Teraz był klasykiem. I tworzył prywatną „mitologię Delty”, przy czym jego teksty wymagały kluczy nieco bardziej skomplikowanych niż osławiony cyrograf Roberta Johnsona, ojca bluesa. Oprócz wpływów pionierów muzyki amerykańskiej pojawiają nawiązania do Keatsa (Not Dark Yet), Dylan cytuje Burnsa (Highlands). Album Love and Theft, prawdopodobnie najlepsza z jego późnych płyt, był konglomeratem odniesień i cytatów, twórczym poszukiwaniem w folklorze amerykańskiego Południa - niezgłębionego, zawsze heroicznego.

Ocalę pokonanych - tak

Tłum mnie wysłucha, wiem 
Ogłoszę pokój podbitym

Dumnych poskromić chcę

[Lonesome Day Blues, 2001]

Teksty ożywia parada postaci mitycznych, literackich, a nawet historycznych. Imiona pary bohaterów Tweedledum i Tweedledee znane są, co najmniej od czasów Byrona, a przynajmniej pojawiają się pierwszy raz w jego znanym epigramie (wymierzonym w kompozytora Georga Friedricha Händela). Postacią autentyczną jest kolejny ojciec bluesa, wymieniony w tytule piosenki High Water (For Charley Patton), jego osoba pełni funkcję symboliczną - podobnie jak, przywołany przed laty, Blind Willie McTell. Dawni bluesmani urastają w tekstach Dylana do rozmiarów biblijnych proroków.

Słyszę płacz pradawnych plemion

Ich kondukt zbliża się

A nikt nie śpiewa bluesa tak

Jak Blind Willie McTell

[Blind Willie McTell, 1983]

Z publikacją albumu Modern Times zbiegły się głosy o nowej dziedzinie dylanologii (analizom twórczości artysty poświęcono już setki książek), jaką jest odnajdywanie w tekstach Dylana odniesień, albo i bezpośrednich zapożyczeń, z tradycyjnych, często anonimowych, utworów bluesowych. Teksty Dylana tylko z tego albumu wymagają przypisów, w których powtarzać się będą takie nazwiska, jak Memphis Minnie, Ma Rainey, Sleepy John Estes, Kansas Joe McCoy, jak również te bardziej znane: Muddy Waters, Willie Dixon, a nawet Chuck Berry. Jak dotąd trylogia Time Out of Mind, Love and Theft i Modern Times (1997-2006) stanowi ukoronowanie drogi artystycznej późnego Dylana. To po niej przyszedł Nobel.

\section{Wielka Próżnia Amerykańska}

Z perspektywy minionego półwiecza nietrudno zauważyć, jak reaguje Dylan, kiedy pojawia się kryzys twórczy. Za pierwszym razem wydawał niedobre płyty. Za drugim dobre, jednak z tradycyjną muzyką ludową. W ostatnich latach, a jako autor milczy już od 2012 roku, nagrywa... amerykańskie standardy. Te piękne, znane dosłownie na całym świecie piosenki z musicali i z filmów, doczekały się już dziesiątek i setek wykonań. Stanowią żelazny repertuar 
muzyków jazzowych. Ten ponadczasowy kanon określa się mianem Wielkiego Śpiewnika Amerykańskiego, a jego źródła to Broadway i Hollywood. Było więc niemałym zaskoczeniem, kiedy na płycie Dylana Shadows in the Night (2015) znalazły się wyłącznie... amerykańskie standardy.

Wcześniej wydał, co prawda, kolekcję piosenek świątecznych Christmas in the Heart (2009), ale był to projekt charytatywny. Teraz mówiło się, że Dylan składa hołd Frankowi Sinatrze, który wszystkie utwory z płyty miał niegdyś w repertuarze. Ale Sinatra miał szeroki repertuar, kiedy zaś Dylan powtórzył pomysł już po roku, wydając bliźniaczą płytę Fallen Angels (2016), było wiadomo, że chodzi tu o co innego. Wielki twórca piosenki oddawał hołd wielkim twórcom piosenek, autorom, którzy kształtowali wrażliwość kilku pokoleń. Konsternację pogłębiło ukazanie się trzypłytowego (!) albumu Triplicate (2017) - ponownie z samymi standardami. Stało się jasne, że nagrodzony literackim Noblem autor piosenek po prostu wydaje własną wersję Wielkiego Śpiewnika Amerykańskiego. Kontrowersje mógł budzić głos Dylana - chropawy, ewidentnie "gasnący", naturalnie ograniczony w skali wiekiem wokalisty. Na pocieszenie pozostawała najwyżej warstwa instrumentalna - zespół, towarzyszący Dylanowi przez kilkanaście ostatnich lat, to wytrawni mistrzowie, wirtuozi, a ich brzmienie stanowi kwintesencję amerykańskiego swingu.

\section{Zakończenie: Dylan po Noblu}

Czy literacka nagroda Nobla zamyka portret artysty? Na pewno nie. Zdumiewające reakcje samego laureata świadczą o tym, że to prestiżowe (w zasadzie historyczne) wydarzenie, dokonało się niejako poza nim. Paradoksalnie, Nobel trafił do rąk Dylana w okresie kolejnego kryzysu twórczego, w samym środku nagrań rozłożonego na pięć kolejnych płyt Wielkiego Śpiewnika Amerykańskiego. A jednak, jak wielokrotnie tego dowodził, Dylan może w każdej chwili zaskoczyć słuchaczy powrotem do kreatywnej formy, nagrać po przewie premierowy materiał. Jego ostatnia do tej pory autorska płyta, Tempest (2012), była nierówna, ale zebrała pięciogwiazdkowe recenzje w najbardziej prestiżowych magazynach muzycznych po obu stronach oceanu (m.in. Rolling Stone i Mojo). Twórczość Dylana jest owocem „natchnienia”, nie pracuje on nad piosenkami długo, nie cyzeluje ich latami, jak czynił to Leonard Cohen. Powiadał, że piosenki przychodzą do niego same, a to oznacza, że mogą przyjść zawsze. 
Tymczasem, dokładnie w rok po przyznaniu Dylanowi Nagrody Nobla, ukazała się nowa kolekcja archiwaliów artysty, trzynasta już, obejmująca okres 1979-1981, czyli fazę religijną. W pełnym wydaniu album The Bootleg Series Vol.13: Trouble No More 1979-1981 prezentuje po raz pierwszy aż sto nieznanych dotychczas nagrań - ze studio i z koncertów - ukazujących, wzgardzonego wówczas, Dylana-kaznodzieję. Najwyższy czas, aby znakomita muzyka artysty z tego okresu zajęła w jego dorobku miejsce, na jakie zasługuje. Faza religijna nie może pozostawać bez wpływu na ocenę całego dorobku artystycznego noblisty, był to zresztą bardzo kreatywny rozdział jego twórczości.

Tajemnica, jaką jest Bob Dylan, będzie się pogłębiać. Artysta nie podpowiada interpretacji, nie daje wskazówek. Unika uproszczeń i pozostaje niewzruszony w swej zagadkowości. Udostępniane archiwalia poszerzają panoramę jego dorobku, zarazem potęgując enigmę. A czy w ogóle istnieją klucze do Dylana? Pytanie: do którego? Jest artystą o wielu twarzach, a mimo to nieustannie zakłada nowe maski. Kluczy do jego twórczości należy szukać w korzeniach amerykańskiej muzyki. W bluesie, country, we wczesnym rock'n'rollu. W poezji modernistów i beatników. W starych balladach i w musicalu. W nowojorskiej dzielnicy Greenwich Village, której kluby wziął szturmem, mając dwadzieścia lat. W pejzażu amerykańskiej drogi, który zdominował malarstwo Dylana - wypełniają je stacje benzynowe, tory kolejowe, motele. Obrazy Dylana wypełnia przerażająca samotność, ona także jest "kluczem” do jego tekstów. Chociaż zawsze trzeba zacząć od delty Missisipi. Dylan jest syntezą, ale ma swoją kolebkę, a leży ona właśnie tam. W spelunkach Nowego Orleanu. Na parkingach przydrożnych barów wokół Atlanty, gdzie śpiewał Blind Willie McTell. Na rozstajnych drogach, na których Robert Johnson sprzedał duszę diabłu. W mitach biorących początek z południowych bagien, nad którymi grają tylko świerszcze. 


\section{Abstract}

\section{Daniel Wyszogrodzki}

ALEKSANDER ZELWEROWICZ NATIONAL ACADEMY OF DRAMATIC ART IN WARSAW

Bob Dylan's Path to the Nobel Prize

Bob Dylan and his work are constantly changing. He closes one chapter only to open another, and in this sense his creative development recalls that of twentieth-century giants such as Pablo Picasso or Miles Davis. Starting off by reinventing a folk tradition in the 1960s, Dylan drew on rock'n' roll and then country and gospel music to find his own musical expression. His music went hand in hand with lyrics that changed the face of popular culture. Dyland broadened the vocabulary of song lyrics, introducing surreal elements and the stream of consciousness. He opened up a popular form to themes that had been untouched. The Nobel Prize for Bob Dylan was a way of honouring both song and a literary genre.

\section{Keywords}

song, protest song, surrealism, musical styles, Delta mythology, Nobel Prize 